\title{
8
}
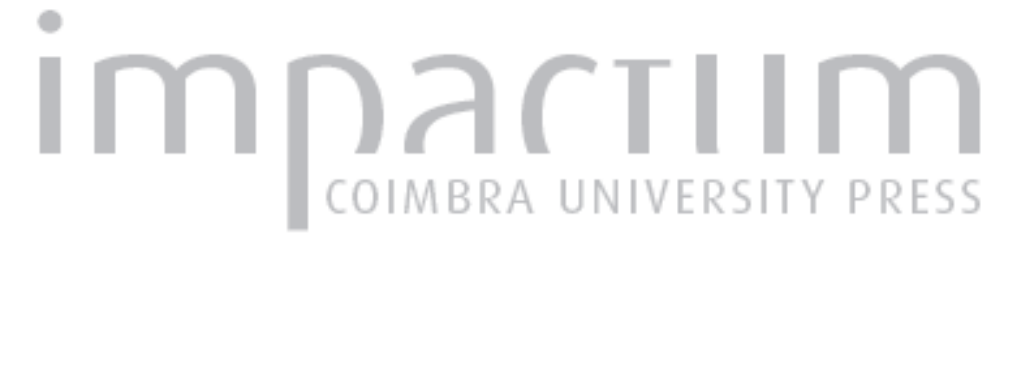

\section{As doutrinas do integralismo lusitano no pensamento e na teoria de acção de Raúl Proença}

Autor(es): $\quad$ Ferreira, Olga de Freitas da Cunha

Publicado por: Imprensa da Universidade de Coimbra

URL persistente:

URI:http://hdl.handle.net/10316.2/45090

DOI:

DOI:https://doi.org/10.14195/2183-8925_7-2_18

Accessed : $\quad$ 26-Apr-2023 15:35:14

A navegação consulta e descarregamento dos títulos inseridos nas Bibliotecas Digitais UC Digitalis, UC Pombalina e UC Impactum, pressupõem a aceitação plena e sem reservas dos Termos e Condições de Uso destas Bibliotecas Digitais, disponíveis em https://digitalis.uc.pt/pt-pt/termos.

Conforme exposto nos referidos Termos e Condições de Uso, o descarregamento de títulos de acesso restrito requer uma licença válida de autorização devendo o utilizador aceder ao(s) documento(s) a partir de um endereço de IP da instituição detentora da supramencionada licença.

Ao utilizador é apenas permitido o descarregamento para uso pessoal, pelo que o emprego do(s) título(s) descarregado(s) para outro fim, designadamente comercial, carece de autorização do respetivo autor ou editor da obra.

Na medida em que todas as obras da UC Digitalis se encontram protegidas pelo Código do Direito de Autor e Direitos Conexos e demais legislação aplicável, toda a cópia, parcial ou total, deste documento, nos casos em que é legalmente admitida, deverá conter ou fazer-se acompanhar por este aviso.

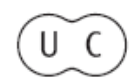




\section{REVISTA DE HISTORIA DAS IDEIAS 7}

\section{REVOLTAS E REVOLUCOẼS}

\section{**}

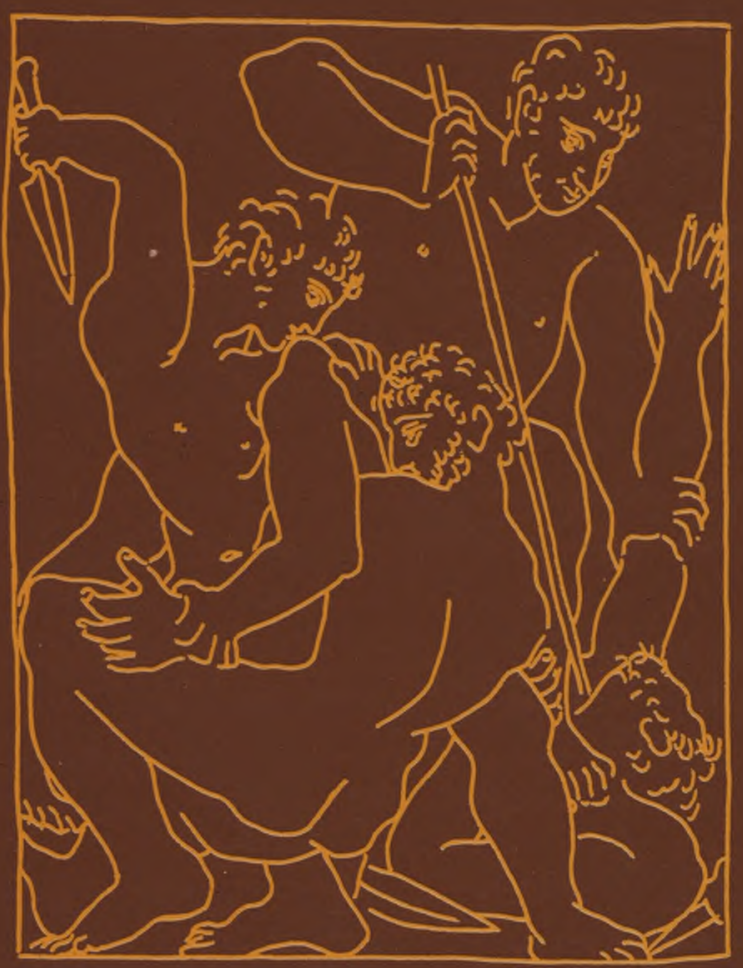

INSTITUTO DE HISTÓRIA E TEORIA DAS IDEIAS FACULDADE DE LETRAS 


\section{AS DOUTRINAS DO INTEGRALISMO LUSITANO \\ NO PENSAMENTO E NA TEORIA DE ACÇÃO DE RAÚL PROENÇA}

1. As Doutrinas do Integralismo Lusitano mereceram no contexto do pensamento de Raúl Proença uma atenção muito especial, como se pode constatar pela série inacabada de artigos saída na revista Seara Nova nos anos de 1921 e 1922, com a designação genérica «Acerca do Integralismo Lusitano» p).

Fugindo ao tom polémico, antes evidenciando profundo respeito intelectual pelos seus adversários, Proença elaborou toda uma crítica onde o desprezo pelos aspectos acidentais cede lugar à preocupação de atingir o essencial daquelas doutrinas, ou seja, os pressupostos filosófico-científicos em que pretenderam encontrar justificação. $\mathrm{O}$ facto de nomearmos explícitamente aquela série de artigos, não significa que as divergências profundas que colocavam os pensamentos de Raúl Proença e dos Integralistas em campos opostos, se lhes circunscrevam. Pelo contrário, elas espraiam-se mais ou menos claramente por muitos outros escritos do autor, o que significa a compreensão segura da importância de uma «filosofia de acção política» que não tendo assentado arraiais apenas em Portugal, aqui con- ${ }^{(*)}$

(*) Faculdade de Letras da Universidade de Coimbra.

O Os artigos referidos são os seguintes: «O que é o integralismo», Seara Nova, de 24 de Dezembro de 1921; "As contradições íntimas do nacionalismo integr alista», idem, de 14 de Janeiro de 1922; «Política das ideias e política do facto», idem, de 1 de Fevereiro de 1922; «Liberdade e Igualdade», idem, de 1 de Março de 1922; «O progresso e as doutrinas científicas», idem, de 1 de Abril de 1922; "Nacionalismo e internacionalismo», idem, de 1 de Julho de 1922. A este conjunto de artigos deveria seguir-se-lhe «O sufrágio e a competência na Democracia», mas Raúl Proença não chegou a continuar a série. 
quistou urna área enorme de inteligências, sobretudo na camada juvenil ( $\left.{ }^{2}\right)$.

A crítica, digamos que sistematizada da série de artigos citada, bem como a que se derrama ao longo da obra do autor, se corresponde por um lado à necessidade de exteriorizar a antipatia intelectual que as doutrinas do Integralismo Lusitano lhe suscitam, não deixam de corresponder por outro às exigências de um intelectual activo, consciente do perigo de uma filosofia de acção, proponente de uma solução política que poderia colocar em risco o ideal por que se batia. Será justo portanto inferir que as críticas de Proença ao Integralismo Lusitano não podem dissociar-se da solidariedade existente entre os pressupostos filosóficos em que se funda a sua concepção do mundo, e os postulados que regem a acção. Quer dizer, a complementaridade do pensamento e da acção em Proença encontra a sua intelegibilidade na correspondência estreita entre o seu modo de perceber o Ser e o que entende por Dever Ser ${ }^{3}$ ). O ateísmo e o imanentismo que assume nega-lhe a possibilidade de aceitar um plano ontológico complementar do mundo terreno e impõe-lhe a necessidade de procurar noutra via um fundamento filosófico para a acção. Radica-o no valor moral que confere à existência humana, valor quase heroico, porque lhe falta precisamente o suporte transcendente que o caucione $\left({ }^{4}\right)$. É portanto, e apenas na consciência, que em Proença reside o fundamento de toda a acção ético-política. Deste pressuposto não se deve contudo concluir uma concepção trágica da existência. Sem revelar um optimismo exagerado, mas sem se deixar imobilizar pelo pessimismo, a sua teoria de acção abre-se à esperança de que o mundo seja permeável às aspirações humanas e permita a materialização do seu ideal democrático. A crença no Progresso que tão pertinazmente defende ao desmontar os fundamentos científicos em que assentava a argu-

${ }^{2}$ Raúl Proença não perfilhava a ideia da generalidade dos adversários do integralismo que negavam aos elementos do movimento talento e cultura. Alguns mereciam-lhe consideração intelectual como António Sardinha, em quem reconhecia talento literário e Poquito Rebelo que admitia ser um especialista de valor. Aliás, todo o grupo, evidenciava segundo Proença um conjunto de virtudes inegáveis como unidade perfeita de vistas, solidariedade moral e espírito combativo que constituiam «a sua glória e a sua força».

Raúl Proença, «Acerca do Integralismo Lusitano», Seara Nova, de 24 de Dezembro de 1921.

(3) Ver Sant'Ana Dionisio, «O pensamento especulativo e agente de Raúl Proença», Revista de Portugal, n. ${ }^{\circ}$, Abril de 1939, pp. 324-339.

(4) Idem. 


\section{Raúl Proença}

mentação integralista com vista a invalidar a ideia de Evolução para colocar no seu lugar a de Tradição, e a esperança que deposita no Futuro, são um reflexo do seu optimismo moderado e prospectivo ${ }^{(5)}$.

Ao colocar na consciência o fundamento da acção, Raúl Proença pretende que esta se apresente liberta de todo o arbítrio moral. Esta atitude move-o a contestar o mecanicismo, o monismo, o epifenomenismo, a fazer uma crítica às doutrinas do eterno retorno nomeadamente de Nietzsche, porque todas conduzem à aceitação do arbítrio e do determinismo de que resultaria a inanidade da acção, na medida em que todas reduzem a pessoa à simples condição de coisa. A identificação destes dois planos do ser repugna-lhe. Se a solução determinista pode aceitar-se no plano das coisas, no domínio do espírito é a liberdade que se lhe apresenta como princípio ontológico, garante de toda a acção livre $\mathrm{e}$ independente. $\mathrm{E}$ quanto mais difícil, mais meritória será essa acção $\left(^{6}\right)$.

Uma certa influência de Antero de Quental e de Oliveira Martins é patente no pensamento de Proença que, tal como aqueles, sentiu a necessidade de corrigir os erros e exageros do cientismo, que, se no terreno científico via muitas explicações aceites, exigia no entanto uma fundamentação idealista para os domínios político, social e moral. O superior não podia explicarle pelo inferior como a epistemología redutora do cientismo de Haeckel, Huxley, Mandesley, Le Dantec e outros permitia. $\mathrm{O}$ espírito distingue-se e é superior à matéria $\left({ }^{7}\right)$. Se esta apro-

(5) Esse optimismo moderado e prospectivo é evidenciado por Câmara Reis no «Prefácio» que antecede as Páginas de política publicadas pela Seara Nova em 1938 e reeditadas em 1972. A esperança de Raúl Proença no futuro, ressalta no autêntico hino "Ao Futuro» que publicou na Seara Nova de 5 de Novembro de 1921 e incluído nas Páginas de Política, Vol. I, Seara Nova, Lisboa, 1972, pp. 23-28. $O$ mesmo acontece com o artigo «O progresso e as doutrinas científicas»" publicado na Seara Nova de 1 de Abril de 1922 e incluída na o5. cit., pp. 85-100. Aí poderá ler-se «Se o passado do homem foi longo, muito mais longo será porventura o seu futuro. Muito mais, pois que os dias que já passaram o farão, o hão-de esculpir e criar os dias que estão para vir.... Esperemos, confiemos. Tenhamos nò tempo uma grande fé. $O$ simples facto de durar é para a humanidade uma grande promessa e uma grande esperança......

(6) Ver Sant'Ana Dionisio, «A atitude crítica do pensamento de Raúl Proença perante a teoria do eterno retorno", Revista de Portugal, n. ${ }^{\circ}$, Coimbra, Julho de 1939, pp. 520-542.

(7) Raúl Proença, «Apresentação de Raúl Proença feita por ele próprio", Seara Nova, N. ${ }^{\circ} 1391 / 1392$ e 1392/1394 de Agosto e Dezembro de 1961, e inserido em Páginas de Política, Seara Nova, 1975, Vol. IV, p. 14.

Sobre as posições de Antero de Quental e Oliveira Martins veja-se de Fernando Catroga, «Filosofia e Sociologia. A Ideia Ante- 
ximação do pensamento de Proença a Antero e a Oliveira Martins é legítima, não o é menos ás correntes neocriticistas e espiritualistas do séc. XIX, sobretudo francesas, onde Renouvier desempenhou papel preponderante $\left.{ }^{8}\right)$. As alusões frequentes ao pensador francês testemunham o apreço em que Proença o deveria ter, pois tal como ele admite a descontinuidade entre os seres e reconhece na pessoa humana um valor próprio em que a liberdade surge como garantia da vida moral e intelectual. Neste contexto, o ideal político-social de Proença, exigindo uma mediação antropocêntrica em que o homem (ser espiritual) surge como a realidade superior, é completamente antagónico ao ideal integralista que, moldado pelo carisma científico e dogmático possuía um carácter imperativo. Com efeito, o ideal político-social proposto pelas doutrinas integralistas apoiava-se em verdades científicas já aceites, sobredeterminando uma teoria de acção a que nada mais restava senão a aceleração da concretização desse ideal já presente na História como um facto. Daí que as prevenções de Raúl Proença face ao Integralismo fossem tanto mais necessárias, quanto uma interpretação de direita do positivismo (Maurras) tendia a anular o papel mediador do sujeito em nome de uma factualidade inerente ao transcurso histórico (Tradição).

As divergências profundas que separam Proença e o Integralismo Lusitano radicam assim num diferendo íntimo, psicológico, consequência de duas atitudes filosóficas opostas. Na verdade, dentro dos pressupostos filosóficos de Proença não cabia de modo nenhum a «política do facto» maurrasiana que o pensador interpreta como uma forma de realismo inferior como um materialismo determinista, incapaz de encontrar para os fins, valores e ideais outro fundamento que não a simples constatação do facto $\left({ }^{9}\right)$. A ideologia integralista apresenta-se assim,

riana de Socialismo», Vértice, Vol. XLII, N. ${ }^{\circ} 488$, 1982, pp. 294-317 e «A ideia de evolução em Antero de Quental», Biblos, LVI, pp. 357-388.

(8) Renouvier foi o principal representante em França do neocriticismo, reacção que em meados do séc. XIX surge não só contra o idealismo absoluto dos seguidores de Kant, mas sobretudo contra o positivismo, o cientismo e o eclectismo. Renouvier, que em alguns pontos capitais se afasta de Kant, nomeadamente na não aceitação do númeno que considera quimérico, manifestou-se fundamentalmente como um moralista e espiritualista. Teve vários seguidores como V. Brochard, Hamelin e L. Dauriac,

(9) Raúl Proença, "Algumas palavras de Proémio», in Páginas de Política, Vol. II, edição da Seara Nova de 1972, p. 11 e ss.; ver também «Inteligência e política», artigo publicado na Seara Nova, n. ${ }^{\circ}$ 271, de 12 de Novembro de 1931 e inserido na ob. cit., Vol. IV, p. 146. 


\section{Raúl Proença}

na óptica de Proença, como uma redução do superior ao inferior, como um fatalismo da Historia, da Tradição e das necessidades inelutáveis $\left(^{10}\right)$. E o mais grave é que é com base nesta filosofia que os integralistas contestam o ideal democrático, precisamente porque fazendo vista grossa de toda a experiência histórica pretendia impor-se violentamente a realidades indestrutíveis, numa violação constante da vida das nações, desviando a consciencia nacional do seu «meio natural», da sua «ideia directriz», numa insurreição dos principios contra os factos $i^{11}$ ). Neste contexto, a democracia é para os Integralistas uma excrescência, assente num conjunto de erros crassos como a adopção do método do livre exame, a crença na falsa ideia do Progresso, a crença na ideia utópica de «Humanidade» e a aceitação da ideia de sufrágio popular (12). Nada mais contraditório com o pensamento de Raúl Proença. Os erros que a doutrina integralista aponta à democracia são as virtudes que lhe reconhece e pelas quais se bate. À doutrina positiva, científica, legitimadora da política do facto, opõe a «política das ideias» que subordina a princípios morais ditados pela consciência, as soluções políticas e sociais, que naqueles princípios encontram o critério justo da sua razoabilidade.

Esta recusa do realismo da «política do facto» não significa desprezo pelos factos, antes reflecte o respeito pela natureza essencialmente racional do homem que aceita aqueles, não porque são factos, mas porque os justifica, os excede, os modifica gradualmente no sentido do desejável (13). É que não são os factos que comandam as atitudes dos homens, mas é o fim, o ideal concebido pelo homem que comanda as atitudes perante os factos $\left({ }^{14}\right)$. Daqui que Raúl Proença se interprete a si mesmo como um idealista realista, justificando sem pretensões de originalidade a conjugação de dois termos aparentemente contra-

(10) Idem, «Apresentação de Raúl Proença feita por ele próprio», in ob. cit., Vol. IV, p. 14.

(“) António Sardinha, Valor da Raça, Lisboa, 1915, p. 21. Ver o jornal a Monarquia, n. ${ }^{\circ} 4,7,80$ e 113 . Vários elementos do movimento integralista como João do Amaral e Pequito Rebelo proclamam o carácter nacionalista do movimento, «essencialmente português» em completa oposição com as ideias importadas que deseducam e desnacionalizam a grei.

(12) Idem, «Pratiquemos um acto de inteligência», Purgatório das Ideias, Lisboa, 1929, pp. 143-180.

(13) Raúl Proença, «Política das ideias e política do facto», Seara Nova, de 1 de Fevereiro de 1922, in ob. cit., Vol. I, p. 76.

(14) Idem, «Inteligência e política», Seara Nova, n. ${ }^{\circ} 271$ de 12 de Novembro de 1931, in ob. cit., Vol. IV, p. 136. 
ditórios $\left({ }^{15}\right)$. Ao considerar-se realista, pretende demarcar-se do idealismo puro para evitar o perigo de que os seus ideais sejam considerados inviáveis por se não prenderem às raízes mesmas da realidade e da vida. Ao considerar-se como idealista, recusa o realismo determinista e intransformista (Integralismo Lusitano), que considera o ideal social dado de uma vez por todas, como um limite infrangível das transformações sociais. O Progresso e a mudança constituem assim ideais proponíveis e deveres impreteríveis que se não compadecem com a constância estulta ou com a fidelidade condenável a um passado cadaveroso. Há que caminhar no Futuro, com esperança na transformação mas sem a pretensão de soluções providencialistas e milagrosas.

E portanto, esta atitude filosófica que sobredetermina e legitima em Proença a sua teoria de acção, que no fundo se plasma no seu tipo de clerc e no papel que lhe reserva.

2. Como já tivemos ocasião de afirmar, as críticas de Proença ao Integralismo Lusitano são indissociáveis da relação estreita que se verifica entre as suas concepções filosóficas e a sua teoria de acção. Se constituem por um lado uma questão de coerência intelectual que só se satisfaz na discussão e invalidação dos princípios fundamentadores das posições dos adversários, resultam por outro de um imperativo moral decorrente do facto de Proença se reconhecer como um intelectual portador de um saber de vocação prática. Só assim se compreende a sua aversão por formas inócuas de cultura e a sua ligação a grupos ou movimentos que se pautavam pelo lema do combate pelos ideais que os norteavam. Estão nesse caso o grupo da Biblioteca e a Seara Nova. Combater as doutrinas do Integralismo constituía para Proença um dever cívico, em perfeita consonância com a missão que a si mesmo impunha, como membro de uma elite intelectual que se pretendia um escol activo, militante, uma elite da boa conscência que face a doutrinas perigosas tinha que assumir uma atitude de protesto $\left({ }^{16}\right)$. Era aliás a

(15) «A conjugação das duas palavras idealismo e realismo, que podiam parecer aqui contraditóras, se não posso, de memória, citar agora precisamente qualquer texto dum «idealista» político que já a tivesse empregado (como Fouillée ou Parodi), no domínio da moral e da política, encontra-se, pelo menos, como síntese operada entre duas atitudes estéticas no Le Rire, de Bergson, e, na metafísica e na teoria do conhecimento, se não em Boutroux. em Hamelin: Ver Raúl Proença, «Algumas palavras de Proémio», in ob. cit., Vol. IV, p. 16.

(16) Idem, «Apresentação da Seara Nova», Seara Nova, N. ${ }^{\circ} 1$, de 15 de Outubro de 1921, in ob. cit., Vol. II, pp. 71-77. 
única atitude que se coadunava com o seu tipo de clerc. O livro de Julien Benda La Thraison des clercs vindo ao encontro das suas preocupações de espírito, permitiu-lhe, ou pela impugnação dos aspectos da obra com que estava em completo desacordo ou pelo esclarecimento de outras, definir o seu tipo de intelectual $\left({ }^{17}\right)$. O pessimismo de Benda face ao moderno clerc não é partilhado por Proença. Nem todos se deixaram corromper pela «revolução capital» que segundo Benda teria transformado os letrados nos motores das paixões políticas, seduzidos pelos bens materiais e pelo desejo de celebridade. Nem todos seriam traidores se Benda lhes desse o direito de poderem intervir na organização de um mundo mais humano, sem abdicarem do seu idealismo e liberdade interior. Mas o autor da Thraison des clerc não thes reconhecia essa possibilidade. O clerc tem que se cingir ao estritamente espiritual pois entre este e o temporal Benda coloca uma barreira intransponível. Esta separação coloca a moral em termos de transcendência e remete para a ordem do absoluto os anseios de igualdade, justiça e verdade, afastando-os do terreno do político, cujo ideal, remetido ao domínio da experiência fica impossibilitado de se justificar em critérios ditados pela consciência. Estavam assim legitimados um Joseph de Maistre, um Bonald, um Maurras e os representantes do Integralismo Lusitano. Politique d'abord, implica um tipo de intelectual que reclama um poder espiritual fundado num carisma científico. A ciência explica as leis naturais e as sociais. $\mathrm{O}$ discurso político moldado nesta mundividência justifica uma acção política determinada pelo imperativo histórico $\left({ }^{18}\right)$. É a capitulação da Moral perante a Política, o que desvirtua a missão essencial do clerc, a de criticar as arbitrariedades, as ditaduras e a de pugnar pelos ideais de liberdade e justiça. Esta sobreposição do facto ao ideal põe em risco a democracia. Para a defender impõe-se como questão prévia, a remodelação do escol intelectual $\left({ }^{19}\right)$ que crie em Portugal um poder espiritual que ilumine as consciências, dite desinteressadamente a verdade e

(1T) Idem, «Para um Evangelho duma acção idealista no mundo realista»; (a propósito de "La trahison des clercs» de Julien Benda). Série de artigos publicados na Seara Nova nos anos de 1928, 1929 e 1930 e inserida na ob. cit., Vol. I, pp. 111-281.

(18) Idem, "Os Letrados e a Política», Seara Nova de 3 de Maio de 1928 e que constitui uma das peças da série referida na nota anterior, in ob. cit., Vol. I, pp. 139-151.

$\left.{ }^{19}\right)$ Idem, «A salvação nacional e os movimentos revolucionários», Seara Nova, n. ${ }^{\circ} 20$, de Janeiro de 1923, in ob. cit., Vol. II, pp. 193-196. 


\section{Varia}

crie a atmosfera indispensável à salvação nacional $\left({ }^{20}\right)$. Justifica-se deste modo para Raúl Proença a utilidade e a necessidade do clerc que possuindo qualidades e recursos não só pode contribuir para o bem-estar social e para guiar a opinião pública, como tem o dever de o fazer, porque poder é dever $\left({ }^{21}\right)$. Essa, a via mais segura de contrariar a influência que sobre aquela opinião poderiam ter os intelectuais da má consciência (Integralistas) que lhe incutiam a convicção de que os remédios para os males da Pátria se encontravam na celebração dos feitos do passado, na exaltação dos seus heróis, na Tradição e na mitifícação de um período paradigmático ao qual urgia regressar. Raúl Proença tinha plena consciência de que as doutrinas do Integralismo não se limitavam a um número limitado de aderentes, mas sabia que progressivamente iam captando maior número de adeptos nas camadas intelectuais juvenis. Esse facto já o reconhecia em 1915, em carta dirigida a Câmara Reis: «Eles têm feito uma propaganda contra a qual nós não temos oposto a menor resistência, e é escusado dizer-lhe quanto essa propaganda pode ser perigosa, principalmente entre a mocidade da escola que é a parte da Nação que mais nos deve importar» $\left({ }^{22}\right)$. A condenação da ditadura e a «propaganda levantada e inteligente da Democracia» são aí consideradas missões prioritárias do verdadeiro democrata $\left({ }^{23}\right)$.

O intelectual, portanto, na óptica de Proença tem de ser activo, interveniente, e manter-se no seu posto como condutor dos povos, sem o direito de renunciar. «Não há nada, absolutamente nada, que dê a alguém o direito de fugir ao cumprimento do seu dever social. O bom marinheiro só abandona o navio quando ele vai ao fundo» $\left({ }^{24}\right)$. Por isso discordou de António Sérgio por ter actualizado o «mito de Vale de Lobos» ao apontar

$\left.\mathbf{i}^{20}\right)$ Idem, «Seria a 'Seara Nova' um partido político sem o saber?», Seara Nova, n. ${ }^{\circ} 14,1$ de Junho de 1922, in ob. cit., Vol. II, pp. 173-178. Para Raúl Proença todas as renovações políticas foram precedidas de renovações espirituais e de grandes movimentos de opinião. "Se essa precedência do intelectual sobre o político tem sido em Portugal matéria desconhecida, é porque o intelectual português tem vivido fora do seu ambiente e do seu tempo, sem sentir os mais altos deveres da vida».

(") Idem, «Os Letrados e a política», in ob. cit., Vol. I, p. 147.

(22) Fernando Piteira Santos, Raúl Proença e a Alma Nacional, Publicações Europa-América, Lisboa, 1979, pp. 50-51.

(*) Idem, ibidem.

(*)Raúl Proença, "Área da Renúncia», Seara Nova, n. 2 de 5 de Novembro de 1921, in ob. cit., Vol. IV, p. 46. Aí afirmava Proença «Meus senhores, é com os pés na lama que nós salvaremos isto. A vileza do meio constitui mais uma razão para não abandonarmos o nosso posto». 


\section{Raúl Proença}

Alexandre Herculano como exemplo para a inteligência portuguesa. A recolha de Alexandre Herculano a Vale de Lobos fora interpretada como um protesto de um homem que não transigia com um mundo amoral e pragmático. $\mathrm{O}$ seu gesto, próprio de um reformador espiritual, mitificou-se e tornou-se paradigmático. Outros lhe seguiriam o exemplo. Antero de Quental encontraria no suicídio o último refúgio. Oliveira Martins, se a morte o não tivesse impedido, teria encontrado na herdade do Chabouco nas Ladeiras de Santarém o seu lugar de retiro $\left({ }^{25}\right)$. Ora o clerc de Proença não se consubstanciava em Alexandre Herculano ou em Antero de Quental. Um tornara-se azeiteiro, o outro suicidara-se. O herói tem que o ser até ao fim. No entanto, a leitura de Sérgio do gesto de Herculano perdurou e não deixa de ser lícito perguntar até que ponto o destino pessoal de Proença não é susceptível de leitura semelhante. Não teria o pensador encontrado na loucura o seu «Vale de Lobos»? De qualquer modo, na sua opinião, não tinha surgido ainda em Portugal um verdadeiro mestre da espiritualidade. É que ser clerc, tal como Proença o concebia, não é fácil. Pautar a vida pessoal e colectiva por princípios éticos ditados pela consciência, subordinar o projecto social a esses princípios exigia elevada coragem moral que tanto permitia o entusiasmo como podia conduzir os menos fortes ao desânimo, à renúncia, ao exílio. $\mathrm{O}$ intelectual deste tipo é normalmente mais um portador de utopias do que um contemporâneo de vitórias $\left({ }^{26}\right)$. Mas para Proença o verdadeiro clerc não pode renunciar nunca. Daí que fizesse da oposição ao Integralismo Lusitano um modo de permanecer constantemente na linha de combate, pela defesa do seu ideal democrático.

3. Do exposto é justo inferir que no contexto do pensamento e da acção de Raúl Proença, «Atacar o Integralismo Lusitano» é o correlato de «Defesa da Democracia». A doutrina que tinha em António Sardinha o principal teórico, preocupava-o pela sua essência íntima, pelo frémito de vida que a animava. Ele mesmo diria «o que me interessa como crítico de ideias políticas, é o efeito global, a influência colectiva e permanente de uma doutrina, a repercussão na vida pública da atitude moral

(25) Ver Fernando Catroga, «Ética e Sociocracia - O exemplo de Herculano na geração de 70», Studium Generale - Estudos Contemporáneos, n. ${ }^{\circ}$, Porto, 1982. Em especial o capítulo «A mitificação de Vale de Lobos", pp. 29-44.

D Idem. Ver especialmente a nota 115, p. 44. 
que ela implica, do dinamismo social que traz em si» $\left({ }^{27}\right)$. Por isso, salvar e defender a democracia do assédio de uma doutrina que colocava em perigo a sua sobrevivência era tarefa imperiosa. A guerra a mover-lhe teria que desdobrar-se em várias frentes. Uma seria colocar em evidência as contradições íntimas do movimento. Assim, a pretensa índole nacionalista que fundada na realidade de Raça sui generis, absolutamente diferenciada, com as suas singularidades inconfundíveis, permitia ao Integralismo reconhecer-se, nas palavras de Pequito Rebelo, «como o lídimo representante do íntegro ideal nacional» $\left({ }^{28}\right)$ que, como afirmava João do Amaral não pactuava com a invasão de quaisquer sensibilidade e mentalidade estrangeiras $\left({ }^{29}\right)$. A essa originalidade fictícia, na óptica de Proença, contrapõe este o carácter estrangeirado daquelas doutrinas e a sua integração num movimento universalista de contestação à democracia. Evidenciar esta contradição é fundamental dado que é em nome do nacionalismo e do tradicionalismo que os integralistas preconizam o fim da República, regime que na sua perspectiva é impraticável num país onde o catolicismo vivido na sua autenticidade evangélica prefigurava uma monarquia tradicional que o deveria substituir. Nesta perspectiva, tornava-se urgente desfundamentar o conceito de Tradição tal como surgia no pensamento integralista, questionando os seus fundamentos biológicos que transpostos para o campo social procuravam garantir a presença constante da Tradição no palco da História, arvorada em motor do ideal político $\left.{ }^{(30}\right)$. Ora Proença, se não admite que a História fosse um simples movimento dialéctico da ideia à maneira hegeliana, também não a concebia como um palco de experiências à maneira integralista. A História não se faz sem ideias, mas para que estas se realizem é necessário que algo de concreto justifique o seu êxito. $\mathrm{O}$ ideal democrático realizou-se. Isto significa que no corpo social algo permitiu esse triunfo - transformações económicas, políticas, sociais. A democracia é portanto a expressão política de um novo modo de estar no mundo. A realidade histórica longe de a invalidar justifica-a. Assim, a Tradição estática, cadaverosa, dos Integralistas, é contrariada pelo próprio fluxo do tempo. Situada no seio da

O $^{7}$ ) Raúl Proença, «Uma Apologia do Fascismo», Seara Nova, n. ${ }^{\circ} 7$ de 13 de Maio de 1926, in ob. cit., Vol. III, p. 168. Este escrito constitui uma resposta ao artigo «O antifascismo de Raúl Proença» publicado por Martinho Nobre de Melo na Reconquista.

(M) Pequito Rebelo, no jornal a Monarquia, n. ${ }^{\circ} 113$.

(i9) João do Amaral, a Monarquia, n. ${ }^{\circ} \mathbf{8 0}$.

(30) Olga de Freitas da Cunha Ferreira, "António Sérgio e os Integralistas», Revista de História das Ideias, 5, 1983, pp. 427-469. 
História que se faz, a democracia representa a verdadeira tradição. Admitir o contrário é cair na anti-história. Neste contexto, o que para os integralistas não passa de quimeras, como a igualdade e a liberdade, são para Proença a conclusão do sentido diacrónico da história. Colocados no terreno da «política do facto» esses ideais surgem aos olhos dos integralistas como uma violentação dos factos que apenas permitem legitimar desigualdades e diferenças. Mas, Raúl Proença sai do campo dos factos para se situar no da consciência que, na linha da lição transcendental de Kant, postula valores éticos, instaura o reino dos fins e define o critério do bem e do mal. A igualdade e a liberdade, essência da democracia, colocadas no plano dos ideais, do Dever Ser, não existem nem se fazem per se. São uma conquista do homem que se revela um criador, um interventor no plano da natureza. Deste modo, a História não contesta mas comprova a democracia não como um facto mas como um fieri, uma realidade realizando-se, encontrando na consciência a sua justificação e a sua garantia ( ${ }^{31}$ ). Se evidenciar as contradições do Integralismo constituía assim uma das linhas de combate pela defesa da democracia, outra não menos importante era a de purificá-la das suas próprias aberrações onde assentavam alguns dos argumentos dos adversários. Isto, implicava para Proença uma definição clara do seu ideal democrático, da República ideal com que sonhava. É uma República liberal, socialista, assente nos direitos do indivíduo e não nos direitos do número. A experiência parecia mostrar-lhe a possibilidade dessa democracia que outras sociedades iam realizando (Inglaterra, Países Escandinavos, Austrália) e que certos doutrinadores defendiam como Renouvier, Fouillé e Welles. Defendendo esta democracia liberal, recusava o totalitarismo democrático que tiveram os seus predecessores nos Sans-Culottes de 93, nos Jacobinos e sobretudo em Rousseau, segundo Proença, o principal mentor do totalitarismo moderno, acima de todos os mestres da contra-Revolução. Não era portanto a democracia de partido em que todos estão de acordo; não era a democracia da unanimidade que se consegue silenciando as vozes discordantes, o que Proença pretendia. Por isso, tanto combateu a monarquia tradicional como a República totalitária e jacobia-

(31) Raúl Proença «Da Defesa da Democracia», 1.a parte, Seara Nova, 10 de Outubro de 1929, in ob. cit., Vol. I, pp. 213-228. Este artigo é dedicado pelo autor ao integralista Hipólito Raposo, que havia escrito recentemente o livro Dois Nacionalismos e a quem Proença trata por «meu querido amigo» 


\section{Varia}

na (32). O seu ideal era uma república progressiva, evolutiva, que pusesse em prática um plano de reformas de natureza económica, social, moral e até política $\left({ }^{33}\right)$. Daqui se infere outra linha de combate pela defesa da democracia. Mais realista, mas em estrita consonância com as anteriores ela vai questionar a república real, a que está à sua frente, para ver até que ponto ela realizou a república ideal, a que está por trás de si. Uma aproximação mais se pode estabelecer entre os pensamentos de Proença e Antero de Quental. No autor oitocentista o pensamento político apontava também para um republicanismo ideal, traduzível numa república social que no entanto não se reconhecia em nenhum momento concreto, ou seja, em nenhuma república real. Essa idealidade funcionaria como um modelo crítico face às repúblicas de facto, das quais Antero de Quental se manifestava adversário porque constituiam deturpações do seu arquétipo. Daí se explique que Antero subalternizasse o problema do regime, e, impelido por imperativos de salvação nacional, defendesse a manutenção ainda que temporária da monarquia, para evitar a anomia social ( $\left.{ }^{34}\right)$.

Proença, ao contrário de Quental não cede na questão do regime. Só a República realizaria o seu ideal democrático. Mas a república real parecia-lhe em crise e o facto que mais a comprometia era precisamente a expansão da ideia monárquica integralista, o que reflecte a inanidade mental do regime. A juventude alia-se à ideologia monárquica porque a república que lhe é oferecida é um monstro sem princípios que permitam afirmar a existência de uma ideologia republicana que

$\left({ }^{82}\right)$ Numa nota às «Palavras de Proémio» Proença aproxima de Rousseau o filósofo alemão Hegel, contrariando uma afírmação de Fouillé que na sua Histoire de la Philosophie afirma que Hegel abandonou a tradição de Kant e Rousseau para regressar à velha concepção do que se poderia chamar um panteísmo político. Proença discorda de Fouillé na medida em que perfilha a tese de que Hegel segue de perto Rousseau de quem é par como doutrinário do totalitarismo, além de mestre do germanismo, da política de invasão e da guerra. Quanto a Kant, na opinião de Proença, Hegel teria separado o Kantismo em dois pedaços, ao distinguir a política da ética. E que para Kant a politica na essência não se distingue da moral, de que não é senão uma aplicação e um caso particular.

Apenas nesta nota há referência de Proença a Hegel. Talvez o facto resulte da grande dificuldade apontada pelo próprio autor, da obtenção de bibliografia alemã, consequência da guerra.

Ver «Palavras de Proémio», nota à p. 32, in oh. cit., Vol. II, p. 56.

$\left.\mathrm{C}^{33}\right)$ Idem, p. 27 e ss.

(M) Fernando Catroga, «O problema político em Antero ${ }^{\wedge}$ de Quental - Um confronto com Oliveira Martins», Revista de História das Ideias, Vol. III, 1981. Em especial a parte referente a «Republicanismo ideal e republicanismo de facto», pp. 409-412. 
garanta a reconstrução do país (35). A sociedade portuguesa chegara a um estado de «obstinação no contrasenso» procurando curar os males nacionais com métodos terapêuticos ineficazes. Daí a necessidade de um conjunto de reformas que permitissem formar uma geração que arcasse com as responsabilidades da independência da pátria ${ }^{36}$ ). Isto só seria possível com o esforço e o apoio de uma elite consciente que ajudasse a formar uma opinião esclarecida $\left({ }^{37}\right)$.

Assim se compreende toda a campanha de Proença, sobretudo a que desenvolveu na Seara Nova, prevenindo contra o perigo de uma ditadura, solução que progressivamente se instalava em muitos espíritos como a mais eficaz. O tempo viria a dar-lhe razão. A ditadura surgiu adornada com um programa de inspiração integralista ( ${ }^{3 S}$ ) por entre os aplausos de monárquicos e muitos republicanos.

(35) Raúl Proença, «A Seara Nova e certas republicanos», Seara Nova, n. ${ }^{\circ} 1$ de 15 de Outubro de 1921, in ob. cit., Vol. II, pp. 79-80.

${ }^{36}$ ) Idem, «A salvação nacional e os movimentos revolucionários», Seara Nova, n. ${ }^{\circ}$ 20, Janeiro de 1923, in ob. cit., pp. 193-196.

(3T) Idem, "Os acontecimentos e a atitude da "Seara Nova», Seara Nova, n. ${ }^{\circ}$, de 1 de Março de 1922, in ob. cit., pp. 161-165.

(38) Idem, "O Programa do Sr. Gomes da Costa: «Integralista por sugestão», Entrevista de Raúl Proença ao jornal $A$ Tarde de 15 de Junho de 1926, in ob. cit., Vol. IV, pp. 207-210. 